\title{
Archaeological collagen: Why worry about collagen diagenesis?
}

\author{
R. C. Dobberstein • M. J. Collins • O. E. Craig • \\ G. Taylor • K. E. H. Penkman • S. Ritz-Timme
}

Received: 5 November 2008 / Accepted: 5 February 2009/Published online: 26 February 2009

(C) Springer-Verlag 2009

\begin{abstract}
DNA appears to decay by random chain scission resulting in a predictable range of fragment lengths. Collagen decay has also been modelled in this same way, although it has become increasingly evident that collagen decay does not follow this same pattern. Radiocarbon and stable isotope analysis now use ultra-filtration to isolate large fragments ( $>30 \%$ of original polymer length) even in Pleistocene bone. How then does collagen decay? This study contrasts experimentally degraded samples with collagen extracted from forensic, archaeological and fossil bone. In experimentally degraded bone, values for amino acid and elemental (C:N) composition, bulk $\delta{ }^{13} \mathrm{C}, \delta{ }^{15} \mathrm{~N}$, and aspartic acid racemisation (AAR) changed very little until $99 \%$ of the collagen was lost, suggesting that the collagen triple helix and polypeptide chains remained remarkably intact. This suggestion was demonstrated directly by examining the integrity of individual polypeptide chains using cyanogen bromide $(\mathrm{CNBr})$ cleavage followed by SDS-PAGE electrophoresis. In ancient samples, AAR values remain remarkably stable and the pattern of $\mathrm{CNBr}$-cleavage was only replaced with a smear of smaller polypeptides in the oldest (Pleistocene) bones investigated. Smearing may reflect both modification of the methionine resides (the sites of CNBrcleavage) and/or partial hydrolysis of the collagen molecule. The findings reveal why it is not usually necessary to worry about collagen diagenesis; it is mostly intact. However,
\end{abstract}

R. C. Dobberstein $(\bowtie) \cdot$ S. Ritz-Timme

Institut für Rechtsmedizin, Universitätsklinikum Düsseldorf,

Moorenstraße 5,

40225 Düsseldorf, Germany

e-mail: Reimer.Dobberstein@uni-duesseldorf.de

M. J. Collins $(\triangle) \cdot$ O. E. Craig $\cdot$ G. Taylor $~ K$. E. H. Penkman

BioArch, Departments of Biology and Archaeology,

University of York,

P.O. Box 373, York YO10 5YW, UK evidence of partial deterioration of the oldest bone samples suggests that alternative purification strategies may increase yields in some samples.

Keywords Bone collagen diagenesis $\cdot$ Amino acid racemisation $\cdot \delta{ }^{13} \mathrm{C} \cdot \delta{ }^{15} \mathrm{C}$

\section{Introduction}

It is logical that information about collagen degradation may enhance the interpretation of palaeo-chemical data (Grupe and Turban-Just 1998), but we are not aware of any investigations, which have considered the contrary, namely why it has not been necessary to understand collagen diagenesis? Polymer hydrolysis is usually assumed to be random, as is apparently the case for both gelatine (Saban et al. 1992) and DNA (Poinar et al. 2006; Deagle et al. 2006), and this assumption underlies models developed for bone collagen diagenesis (e.g. Rudakova and Zaikov 1987; Riley and Collins 1994; Collins et al. 1995); all the evidence suggests that these models are wrong.

For example, random chain scission predicts a rapid decline in modal peptide length, but radiocarbon laboratories (Brown et al. 1988; Ramsey et al. 2004; Higham et al. 2006 ) routinely date the $>30 \mathrm{kDa}$ gelatine fraction $(>30 \%$ of initial polymer length) which clearly persists in bone of considerable antiquity. It is instructive to contrast the relative ease of 'collagen' purification with the difficulties encountered when ${ }^{14} \mathrm{C}$ dating of the second most abundant bone protein, osteocalcin (Aije et al. 1990, 1991, 1992; Burky et al. 1998).

Bone amino acid profiles are surprisingly consistent (and collagen like) and retain unstable amino acids such as methionine (Jope 1980) until levels are very low (Hare 
1980; Masters 1987). Bulk characteristics of the insoluble fractions such as $\mathrm{C}: \mathrm{N}$ ratio (2.8-3.1; DeNiro 1985; van Klinken 1999) and aspartic acid racemisation (D/L 0.060.1) (e.g. Matsu'ura and Ueta 1980; Kimber and Hare 1992) are consistent over long time scales. The degree of aspartic acid racemisation in Neanderthal bone (Serre et al. 2004) is exceeded in modern coral skeletons in less than a decade (Goodfriend et al. 1992).

Tuross et al. (1980) developed an elegant approach to assess the state of preservation using electrophoretical separation of cyanogen bromide (CNBr) digests - a method commonly used in collagen analysis (Volpin and Veis 1973; Fietzek et al. 1972; Van der Rest and Fietzek 1982; Knott et al. 1997) - to provide a 'fingerprint' of the molecular integrity of ancient collagen. Methionine is prone to oxidation, consequently retention of a clean $\mathrm{CNBr}$-fingerprint monitors both hydrolysis (fragment size) and oxidation (cleavage sites). In humans, there are only twelve Met residues within the type I collagen sequence -7 of 1,057 in $\alpha 1$ (I) and 5 of 1,040 in $\alpha 2$ (I) - and therefore only 14 cleavage products $(\mathrm{CNBr}-$ peptides) will result, 8 from $\alpha 1$ (I) and 6 from the $\alpha 2(\mathrm{I})$; a tractable number to fingerprint. Finally, the localisation of individual CNBr-peptides in the $\alpha 1$ (I)- and $\alpha 2$ (I)-chains and their primary structure are well established (Piez and Reddi 1984) and quite conserved, the largest fragment assuming no missed cleavages being $31 \mathrm{kDa}$. Consequently any changes in the fingerprint pattern can be interpreted in terms of targeted decomposition.

Tuross et al. (1980) observed excellent preservation of the $\mathrm{CNBr}$-fingerprint in bones from high latitudes but smears (of variable molecular weight) as predicted by the polymer degradation model from bones from a 500-year-old Moa bone (New Zealand, cave), La Brea Tar Pit and an Egyptian mummy. Using a similar approach Schaedler et al. (1992) observed some intact CNBr-fragments in a single Pleistocene mammoth from high altitude in central Utah.

In this paper, we use $\mathrm{CNBr}$ digestion to assess the integrity of the collagen molecule in both artificially heated and in ancient bone. We explore the change in amino acid composition using HPLC and elemental $(\mathrm{C}: \mathrm{N})$ analysis. We explore the relationship between isotopic ratios of collagen carbon and nitrogen with the extent of deterioration. Finally we examine the stability of aspartic acid racemisation, a method used for both dating and the prediction of DNA survival.

\section{Material and methods}

Experimental heat degradation of bone samples

For simulating bone collagen degradation, equally sized human and bovine bone pieces were heated in sealed tubes under water at $90^{\circ} \mathrm{C}$ in a heating cabinet.

\section{Preparation of bone samples for artificial digenesis}

Human bone (diaphysis, femur compact bone, mature adults) samples were taken routinely in the course of postmortem examinations (following ethical committee approval). Bovine femurs were obtained from a local butcher. Remaining soft tissue was removed mechanically, the diaphysis was cut into halves longitudinally, spongiosa and outer compact bone were removed using a milling cutter. The remaining pure compact bone was cut into small pieces of approximately $0.75 \mathrm{~cm}$ side-length.

\section{Washing steps}

Bone pieces were washed overnight in $15 \% \mathrm{NaCl}$-solution containing protease inhibitors (66 g 6-amino-n-hexanic acid, $3.9 \mathrm{~g}$ benzamidine $\mathrm{HCl}, 625 \mathrm{mg}$-ethylmaleimide, $522 \mathrm{mg}$ phenylmethylsulfonyl fluoride dissolved in $1 \mathrm{~L}$ of distilled water; Takagi and Veis 1984), lipids were extracted using ethanol/ether (v/v 3:1) for $15 \mathrm{~min}$ and the bones were again washed in $2 \%$ SDS-solution containing protease inhibitor for $1 \mathrm{~h}$. All washing steps were conducted at $4^{\circ} \mathrm{C}$ on a rocking table and followed by 4-5 rinses with double distilled water. After lyophilisation the samples were stored at $-20^{\circ} \mathrm{C}$.

\section{Heating}

Washed bone pieces were heated in sealed Pyrex glass vials under wet conditions ( $10 \mathrm{ml}$ distilled water $\mathrm{g}^{-1}$ bone) at $90^{\circ} \mathrm{C}$ for a maximum duration of 32 days. Sub-samples, including $5 \mathrm{ml}$ of the supernatant (leached fraction [LE]) were taken after 1, 2, 4, 8, 12, 16, 20, 26 and 32 days of incubation. After heating, the vials were cooled, decanted and lyophilised for subsequent preparative steps. As a reference, an unheated sample of bovine femur ( 0 days) compact bone was analysed following the same protocols.

\section{Archaeological bone samples}

In total, 89 archaeological bone samples were analysed. The age (obtained from radiocarbon and stratigraphic dating), origin, and description of each sample are summarised in Table 1. Ancient bone samples were cleaned using a Dremel drill with a dentist's diamond and tungsten carbide rotary tools. The preparation of the archaeological bones is identical to that just described in the preceding section.

Demineralisation, preparation of a total bone fraction (TB), "collagenous" protein fraction (CF) and leached fraction (LE)

Dry artificially degraded and archaeological bone samples were powdered using a hydraulic press and a mixer mill (PO Weber, Remshalden, Germany; Retsch, Hahn, Germany). An 
Table 1 Characterization of the archaeological material

\begin{tabular}{|c|c|c|c|c|}
\hline Age [years] & Origin & Sample description & $\begin{array}{l}\text { Number of } \\
\text { specimens }\end{array}$ & $\begin{array}{l}\text { Collagen yield } \\
{[\% \text { dry weight }]}\end{array}$ \\
\hline 500 & $\begin{array}{l}\text { Northern Germany, Schleswig-Holstein, } \\
\text { Hemmingstedt }\end{array}$ & $\begin{array}{l}\text { Human femurs, war grave } \\
\text { in marshy soil }\end{array}$ & 4 & $18.9-22.3$ \\
\hline $400-700$ & Northern Germany, Schleswig-Holstein, Flensburg & Human femurs from burial & 14 & $5.5-24.2$ \\
\hline 1,700 & Southern Germany, Rheinland-Pfalz, Trier & Human femurs from burial & 27 & $3.5-27.7$ \\
\hline 1,700 & Italy, Grumentum & Human femurs from burial & 4 & $3.7-8.3$ \\
\hline $2,480-6,380$ & $\begin{array}{l}\text { Eastern Germany, Sachsen-Anhalt, Braunsdorf, } \\
\text { Merseburg/Querfurt; Derenburg, Wernigerode; } \\
\text { Eilsleben, Bördekreis; Freyburg, } \\
\text { Burgenlandkreis; Halle-Beesen; Queis, } \\
\text { Quennstedt, Questzdölsdorf, Stedten, } \\
\text { Saalkreis; Unseburg, Aschersleben; } \\
\text { Westerhausen, Quedlinburg }\end{array}$ & $\begin{array}{l}\text { Diverse human, bovid, } \\
\text { equid remains }\end{array}$ & 20 & $1.8-15.4$ \\
\hline$\sim 30,000$ & Great Britain & Bos primingenius, Os cornu & 1 & 17.9 \\
\hline$\sim 200,000$ & Great Britain & $\begin{array}{l}\text { Mammuthus primigenius, } \\
\text { scapula }\end{array}$ & 1 & 18.5 \\
\hline $235-49,360$ & $\begin{array}{l}\text { North America: Boyer River Reserve, Fort } \\
\text { Vermilion, AB Can; Cloverbar Pit, Edmonton, } \\
\text { AB Can; Gallelli Pit, Calgary, AB Can; } \\
\text { Panther R., Banff NP, AB Can; Ikpikpuk R., } \\
\text { North Slope, AK USA; Natural trap cave, } \\
\text { WY USA } \\
\text { Siberia, permafrost: Kolyma lowland, } \\
\text { Duvanny Yar, Siberia Rus } \\
\text { Central Asia: Tong He, China; Yanjiagang site, } \\
\text { Harbin, China }\end{array}$ & $\begin{array}{l}\text { Bison bison, various } \\
\text { skeletal fragments }\end{array}$ & 18 & $5.2-20.0$ \\
\hline
\end{tabular}

aliquot of powder was hydrolysed directly (TB) for amino acid racemisation analysis. Remaining bone powder was demineralised overnight in $1 \mathrm{M} \mathrm{HCl}(10 \mathrm{ml} \mathrm{HCl}$ per $500 \mathrm{mg}$ bone powder). The acid insoluble collagenous fraction (CF) was separated and washed until neutral $\mathrm{pH}$ and subsequently lyophilised. The collagen yield was estimated from the dry weight of the CF per dry weight of total tissue. A leached fraction (LE) was obtained lyophilising of $5 \mathrm{ml}$ of aqueous supernatant.

Elemental, $\delta^{13} \mathrm{C}$ and $\delta^{15} \mathrm{~N}$ analyses

Elemental analysis $(\mathrm{C}: \mathrm{N})$ is commonly used as a screening method for collagen purified for radiocarbon dating and stable isotope analysis. The ratio is surprisingly stable (van Klinken 1999) but tends to increase in bones yielding low levels of collagen. We suspect that $\mathrm{C}: \mathrm{N}$ ratio stability is another atypical characteristic of collagen diagenesis and therefore we contrasted the relationship between the integrity of collagen as estimated by $\mathrm{CNBr}$ against this measure. Additionally, we measured the $\delta^{13} \mathrm{C}$ and $\delta^{15} \mathrm{~N}$ to identify any variability against the diagenetic parameters.

Collagen residues were gelatinised with $1 \mathrm{mM} \mathrm{HCl}$ at $65^{\circ} \mathrm{C}$ for $24 \mathrm{~h}$ and the resulting solution was centrifuged to remove insoluble material and lyophilised for analysis by elemental analyser isotope ratio mass spectrometry (EAIRMS). Each sample was weighed (ca. $500 \mu \mathrm{g}$ ) in duplicate into tin capsules which were analysed using ANCA-SL elemental analyser linked to a PDZ Europa 20/20 mass spectrometer (PDZ Europa Ltd, Crewe, UK). Measurements were made in relation to a reference (albumin) with known $\% \mathrm{C}$ and $\% \mathrm{~N}$ and traceable to international V-PDB and AIR standards. The analytical precision of isotopic determinations based on repeated measurements was better than $0.2 \%$ in both cases.

Estimating the bulk parameters from amino acid compositional data

We contrasted bulk measurements $\left(\mathrm{C}: \mathrm{N}, \delta^{13} \mathrm{C}\right.$ and $\left.\delta^{15} \mathrm{~N}\right)$ with values estimated using amino acid composition data. In our analysis, His, Lys and Arg were not reliably estimated and the imino acids Pro, Hyp, were not measured at all. Therefore, in order to obtain $\mathrm{C}: \mathrm{N}$ and isotope estimates, the proportion of these 'missing' amino acids was estimated relative to measured glycine using ratios in published collagen compositions (Vaughn 1975 cited in Howland et al. 2003). To estimate atomic C:N ratios, the 
total number of $\mathrm{C}$ and $\mathrm{N}$ atoms was estimated from the amino acid compositional data (His, Lys, Arg, Pro and Hyp all estimated). To estimate isotope shifts, the $\delta^{13} \mathrm{C}$ composition of individual amino acids was averaged from published data on collagen (Howland et al. 2003; Fogel and Tuross 2003; Tripp et al. 2006; Jim et al. 2006) as $\delta^{13} \mathrm{C}$ relative to (Asp, Gly, Ala, Phe). Testing these data against the dataset of Corr et al. (2005) revealed that this crude approach gave only a modest correlation with bulk collagen $\delta^{13} \mathrm{C}$ (estimate 0.89 observed, $R^{2}=0.88, n=26$ ). $\delta^{15} \mathrm{~N}$ composition data was taken from Tripp et al. (2006).

Preparation and separation of CNBr-peptides

\section{CNBr-cleavage}

CNBr-cleavage of purified collagen, was conducted using a combination of methods from Scott and Veis (1976) and Rossi et al. (1996). In brief, $40 \mathrm{mg}$ of CF was suspended in $10-15 \mathrm{mg} \mathrm{ml}^{-1}$ of a solution consisting of $10 \%$ 2-mercaptoethanol in $10 \mathrm{mM} \mathrm{NH}_{4} \mathrm{HCO}_{3}$ for $4 \mathrm{~h}$ at $45^{\circ} \mathrm{C}$ to reduce oxidised methionine residues. The supernatant was removed following centrifugation and the samples were lyophilised. The samples were then suspended in $4 \mathrm{ml}$ of nitrogen flushed $70 \%$ formic acid with $200 \mathrm{mg} \mathrm{CNBr}$, which was then incubated at $26^{\circ} \mathrm{C}$ for $4 \mathrm{~h}$ with continuous stirring. The reaction was stopped by lyophilisation and aliquots taken for electrophoretic analysis.

\section{Separation of the CNBr-peptides by SDS gel electrophoresis}

CNBr-peptides were separated by SDS-PAGE (Laemmli $1970)$ on $12.5 \%$ polyacrylamide gels overnight $(17 \mathrm{~h}$, starting at constant current of $8 \mathrm{~mA}$, and a variable voltage of about $40 \mathrm{~V}$ ) using a Protean II XI cell (Biorad, Munich, Germany). Gels were stained with Coomassie blue for $1 \mathrm{~h}$ and differentiated until the bands were clearly visible.

\section{Crude molecular weight separation by gel filtration}

CNBr-cleaved collagen was dissolved in $0.1 \mathrm{~N}$ acetic acid, and crudely filtered over paper (type 581/2; Schleicher \& Schuell, Dassel, Germany). Gel-filtrationcolumns (PD-10, Sephadex G25-M, Amersham Biosciences, Munich, Germany) were prepared following the manufacturer's instructions. $1 \mathrm{ml}$ of the $\mathrm{CNBr}$-peptide solution was loaded onto each column and eluted with $15 \mathrm{ml}$ of $0.1 \mathrm{~N}$ acetic acid. Fractions of $1 \mathrm{ml}$ volume each were collected, the relative concentration of peptides was monitored as extinction at a wavelength of $\lambda=$ $220 \mathrm{~nm}$ and $\lambda=280 \mathrm{~nm}$ respectively. SDS-PAGE was used to control the success of the gel filtration; an aliquot of
$100 \mu 1$ from each PD-10-fraction was loaded onto a $12 \%$ acrylamide gel (mini cell, Biorad, Munich, Germany) and run using standard conditions $(200 \mathrm{~V}, 60 \mathrm{~mA})$.

Analysis of racemisation in crude extracts and $\mathrm{CNBr}$-fragments from experimentally aged and archaeological bone

It has previously been argued that aspartic acid racemisation (AAR) is retarded in the collagen triple helix (van Duin and Collins 1998). Aspartic acid racemisation therefore served as a marker for the extent of helical integrity in the individual $\mathrm{CNBr}$-fragments. Standard hydrolysis conditions for age estimation in a forensic context, of $6 \mathrm{~h}$ at $100^{\circ} \mathrm{C}$, were chosen to minimize the induced racemisation of aspartic acid during hydrolysis (Ritz et al. 1993, 1994, 1996).

During preparative hydrolysis asparagine undergoes rapid irreversible deamination to aspartic acid (Hill 1965). It is therefore not possible to distinguish between the amino acid and its amide derivative; these are therefore reported together as Asx.

\section{Analysis by RP-HPLC}

A total of $900 \mu 1$ of the column-eluted fractions (i.e. the total after $100 \mu \mathrm{l}$ had been taken for SDS-PAGE-analysis, above) were lyophilised for AAR analysis. Lyophilisates of the eluted peptides were hydrolysed in $6 \mathrm{~N} \mathrm{HCl}$ at $100^{\circ} \mathrm{C}$ for precisely $6 \mathrm{~h}$, and dried in vacuo. Hydrolysates were redissolved in $0.01 \mathrm{~N} \mathrm{HCl}$, containing $0.03 \mathrm{mM} \mathrm{L}$-h-arginine as an internal standard, and $0.77 \mathrm{mM} \mathrm{NaN}_{3}$ to inhibit bacterial growth. Samples were analysed on a Agilent 1100 Series HPLC (Agilent Technol., Germany) consisting of a programmable injector unit, quaternary pump and fluorescence detector following a slightly modified onlinederivatisation protocol of Kaufmann and Manley (1998). Samples were derivatised with iso-butyryl-L-cysteine (IBLC) and $o$-phthaldialdehyde (OPA) in a potassium borate buffer system (1 M, pH 10.4) and separated on a C18-column (Hypersil BDS, $5 \mu \mathrm{m}, 250 \times 4 \mathrm{~mm}$, Thermo Hypersil-Keystone, Thermo-Finnigan Corp., Waltham, USA). General detector settings were chosen as described by Kaufman and Manley (1998) unless otherwise stated. Amino acid derivatives were excited at a wavelength of $230 \mathrm{~nm}$, the fluorescence-emission was detected at $445 \mathrm{~nm}$. During the analysis a gradient of the eluents A $(95-48 \%)$, B (5- 50\%) and $C(0-2 \%)$ within 95 min was programmed, followed by a post-run consisting of flushing the column with $95 \% \mathrm{~B}+5 \% \mathrm{C}$ for $15 \mathrm{~min}$ and equilibration for another 5 min with $95 \% \mathrm{~A}+5 \%$ B for $5 \mathrm{~min}$ (A: $23 \mathrm{mM}$ sodium acetate, $1.5 \mathrm{mM}$ sodium azide, $\mathrm{pH}$ 6.00; $\mathrm{B}$ : methanol, HPLC-grade; C: acetonitrile, HPLC-grade). A flow rate of $0.56-0.6 \mathrm{ml} \mathrm{min}{ }^{-1}$ was used during analysis 
and post-run. AAR is expressed as the $\mathrm{D} / \mathrm{L}$ value [\%] of the D- and L-enantiomers of an amino acid. All samples were analysed at least in duplicate.

\section{Analysis by $G C$}

The extent of aspartic acid racemisation was determined as described by Ritz et al. (1993) and Ritz-Timme (1999), taking into account defined quality standards (Ritz-Timme et al. 2000). Briefly, the dried samples were hydrolysed in $6 \mathrm{~N} \mathrm{HCl}$ at $100^{\circ} \mathrm{C}$ for $6 \mathrm{~h}$. Hydrochloric acid and water were removed in a vacuum and the dry hydrolysate was esterified with isopropanol/sulfuric acid (10:1) for $1 \mathrm{~h}$ at $110^{\circ} \mathrm{C}$. After alkaline extraction with dichloromethane, acetylation was performed with trifluoroacetic anhydride (TFAA) at $60^{\circ} \mathrm{C}$ for $15 \mathrm{~min}$. Amino acids were now present as TFA-isopropylesters. The ratio of D-aspartic acid to Laspartic acid was determined after separation of the amino acids by gas chromatography (GC9, Shimadzu, Duisburg, Germany) on a chiral capillary column (Chirasil-L-Val, Varian, Middelburg, The Netherlands) using a flame ionisation detector, with hydrogen as carrier gas. The samples were analysed at least in duplicate. The extent of AAR was calculated as described above.

\section{Results}

Experimentally aged human bone

\section{Collagen loss}

The pattern of collagen loss was sigmoidal as previously reported by Rudakova and Zaikov (1987) and Okada et al. (1992; Fig. 1a); a pattern which lead to the original proposition of the polymer models of collagen degradation, which emphasised random cleavage and stabilisation by intra-helical hydrogen bonding (Collins et al. 1995). The C: $\mathrm{N}$ ratio (Fig. 1b), the $\delta^{13} \mathrm{C}$ (Fig. 1c) and $\delta^{15} \mathrm{~N}$ isotope values (Fig. 1d) of the insoluble fraction within the bone pattern all remain surprisingly constant, until this fraction represent less than $1 \%$ of the total bone mass (Fig. 2). Shifts were consistent with computed values based upon amino acid compositions (Fig. 2) for all but low collagen $(<1 \%$ ) bone.

Using the predicted change in composition of amino acids between 'high' and 'low' collagen bone (Fig 2.), it is possible to compute changes in the $\mathrm{C}: \mathrm{N}$ ratio and, using published isotope data of individual collagen amino acids, estimate the impact on isotopic composition. This exercise reveals that although the relatively small shift observed in $\delta^{13} \mathrm{C}(-2.6 \%$ ) can be explained (Fig. 1c), changes in amino acid composition alone cannot account for the elevated $\mathrm{C}: \mathrm{N}$ ratio in low collagen bone. Without knowing the isotopic composition of the additional $\mathrm{C}$ source, it is difficult to interpret this data further. In the case of $\delta^{15} \mathrm{~N}$, the lack of published data coupled with the unknown isotopic effects of deamidation hampers interpretation.

\section{Amino acid racemisation}

The pattern of racemisation also mirrors the loss of collagen (Fig. 1a). The extremely rapid initial racemisation of the telopeptide (1) is captured only by the high intercept at the onset of the experiment (see Waite and Collins 2000). Following this, there was a gradual increase in racemisation (2) rising slowly as the bulk of collagen is lost. Once total collagen was below $1 \%$, racemisation shifted along with the other bulk measurements (3). Curiously, by the end of the experiment the value had not reached equilibrium (D/L of 1) instead values reached a plateau with a $D / L$ ratio of 0.53 (4), indicating that approximately $30 \%$ of the remaining DAsp residues are in non-racemisable positions (Fig. 1a).

\section{Electrophoretic pattern of CNBr-fragments}

from experimentally aged bovine bone samples

In a second experiment (compact bone of a 4-year-old cow), a similar pattern of decay is observed (Fig. 3), but the rate of weight loss is considerably faster $(>1 \%$ in 8 days, rather than 23 days). Remarkably, the $\mathrm{CNBr}$-digest pattern is maintained until day $8(0.09 \%$ collagen in bone $)$. Beyond this point, not only is the CNBr-banding lost, the amino acid profile also no longer resembles collagen being relatively depleted in glycine (data not shown).

\section{AAR in CNBr-fragments of different molecular weights in experimentally aged bovine bones}

After column separation of the CNBr-peptides according to their molecular weights, a high-molecular-weight- component (MW > ca. $3.5 \mathrm{kDa}$, fractions $1-4$ in Fig. 4a) was well separated from a low-molecular-weight-component (fractions $>6$ in Fig. 4a), as demonstrated by the electrophoretic pattern of these peptides in SDS-PAGE electrophoresis (Fig. 4b). Racemisation analysis revealed an approximate doubling in values of D-Ser in fraction 6 and slight elevation of D-Asxlevels in fraction 6, which upon heating increased differentially in this and later eluting fractions (Fig. 5).

\section{Archaeological bone}

\section{AAR in crude extracts of archaeological bone}

Amino acid racemisation of archaeological bones ranged from $2 \%$ to $11 \% \mathrm{D}$-Asx and there is no clear trend with chronological age (Fig. 6). The oldest samples $>40 \mathrm{ka}$ 
Fig. 1 Changes occurring in old (cross-linked) collagen after experimental degradation at $90^{\circ} \mathrm{C}$. a Loss of collagen was weight percentage of total bone, and racemisation of aspartic acid as D/L-AAR. Observed and predicted changes in the $\mathbf{b}$ atomic $\mathrm{C}: \mathrm{N}$ ratio $\mathbf{c} \delta^{13} \mathrm{C}$ and $\mathbf{d}$ $\delta^{15} \mathrm{~N}$ values of the insoluble 'collagen' extract. Amino acid analysis failed to detect imino acids and others are poorly resolved. Their composition was estimated (Fig. 2) in order to explore whether the observed changes could be the result of the altered amino acid profile. In the case of $\mathrm{C}: \mathrm{N}$, the shift in ration is much larger than predicted. Isotope analysis of single amino acids would be required to properly interpret the isotope shifts
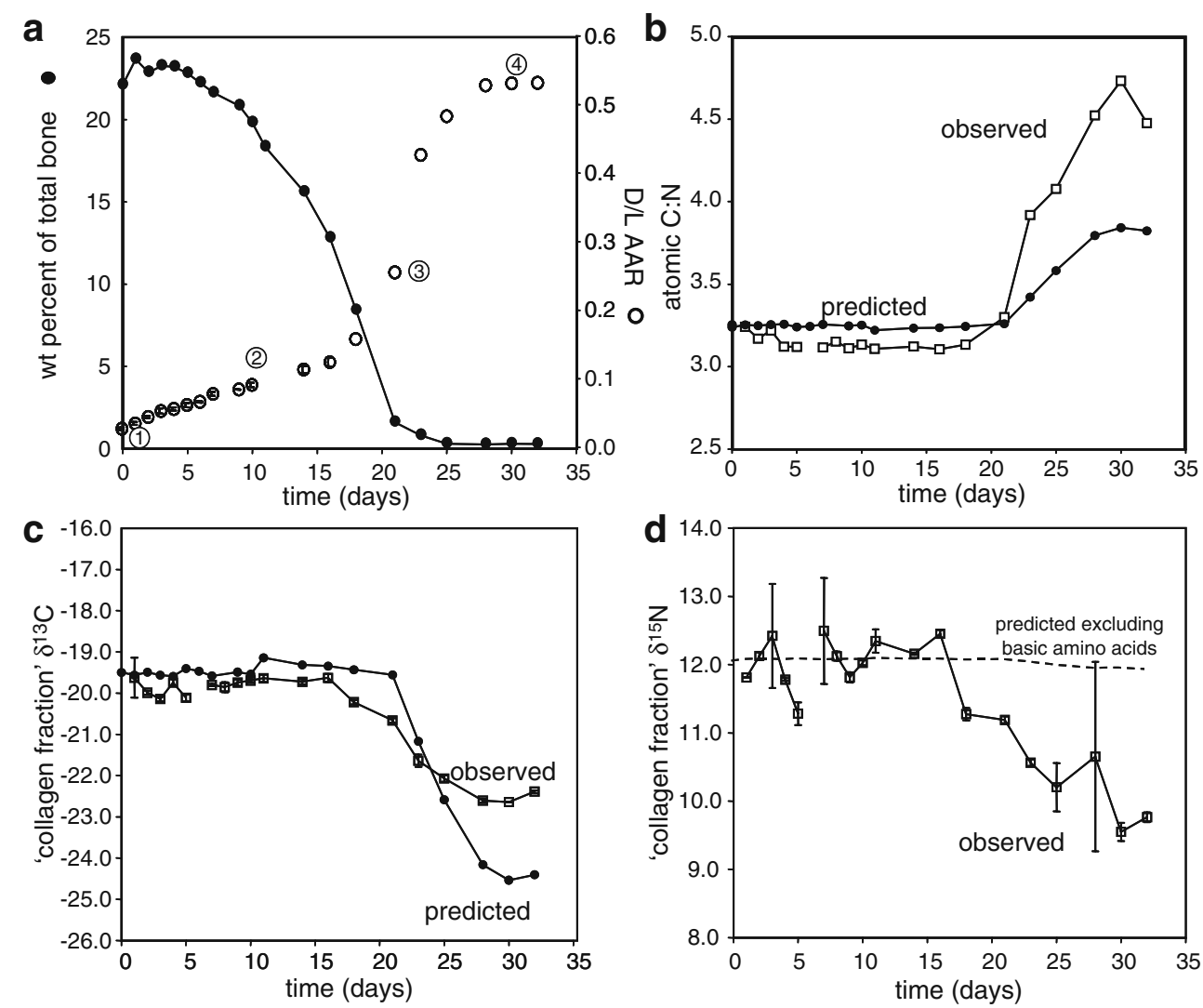

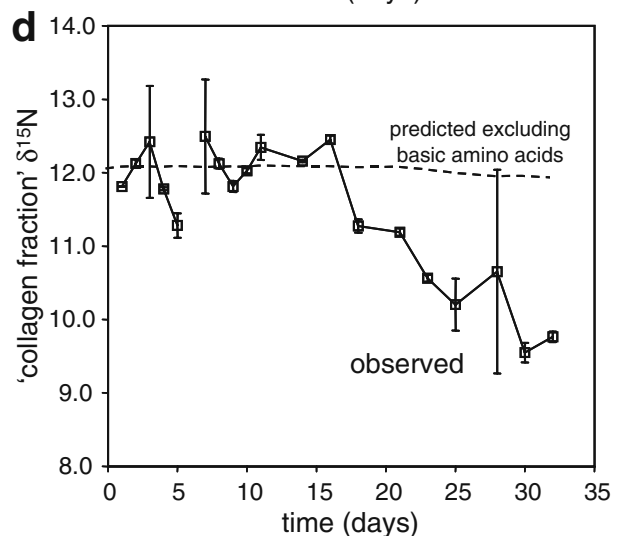

exhibit low D-Asx ratios (ca. 5\%) and high collagen yields (Fig. 6 insert). This is because these bones originate from high latitudes, predominantly permafrost sites. In order to correct for differences in the temperature of the burial environment we calculate the time required for the same degree of collagen degradation at $10^{\circ} \mathrm{C}$ (assuming an activation energy of $173 \mathrm{~kJ} \mathrm{~mol}^{-1}$ for loss of collagen from

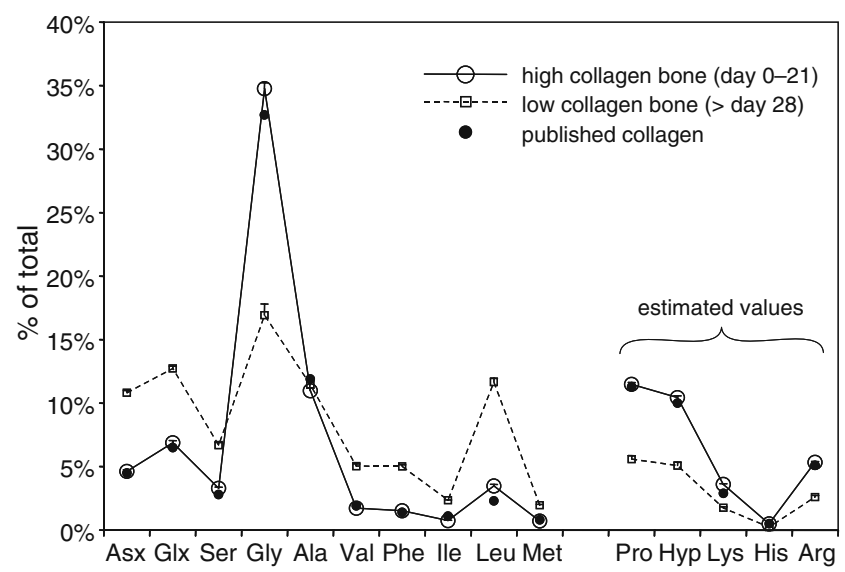

Fig. 2 Amino acid profiles of experimentally degraded (at $90^{\circ} \mathrm{C}$ ) collagenous fractions (human bone). Estimated values of amino acids not well resolved or not measured (Pro, Hyp, Lys, His, Arg) are illustrated. Their values were based upon their proportional values in type I collagen, relative to glycine (the dominant amino acid in collagen) in order to predict the values for $\mathrm{C}: \mathrm{N}, \delta^{13} \mathrm{C}$ and, $\delta^{15} \mathrm{~N}$ in Fig. 1 bone), this we term thermal age (Smith et al. 2003). Thermal age normalizes the age samples from different latitudes based upon the using a predetermined activation energy for molecular degradation. When, however, the thermal ages are plotted (estimated using for collagen degradation) a clearer trend emerges, but, nevertheless, values are increasingly scattered with thermal age (Fig. 6a). The collagenous fraction $(\mathrm{CF})$ appears to rise by approximately $0.5 \%$ within the first 300 years, but in the next $10 \mathrm{ka}$ it plateaus out at about $2.5 \%$ higher than the youngest samples. The AAR values of the total bone fraction (TB) scatter on a higher level compared to the CF-values.

\section{Electrophoretic pattern of CNBr-fragments \\ from archaeological bone samples}

Archaeological bones from the last millennia (Fig. 7a) displayed almost no evidence of collagen deterioration, the CNBr-peptide patterns being nearly identical to that of modern bone irrespective of total collagen yield (Fig. 7b). If a wider range of human and animal bone was examined again in most cases the CNBr-pattern was retained (Fig. 7b). There was no correlation between collagen integrity (as revealed by $\mathrm{CNBr}$-fragment patterns), with either yield or absolute age. However, if age is recalculated to account for the temperature history of a site (ignoring, in 

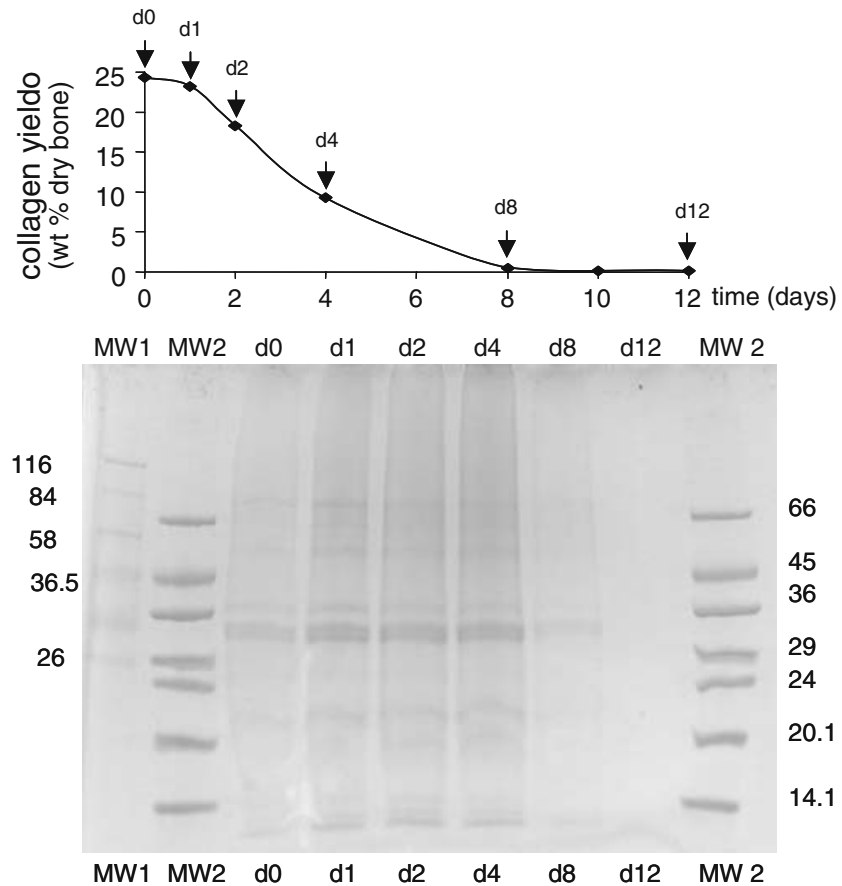

Fig. 3 Electrophoretic pattern of $\mathrm{CNBr}$-fragments from experimentally degraded young (poorly cross-linked) bovine bone. Lane $d 0$ depicts the typical CNBr-peptide pattern of an untreated bone sample; lanes " $d 1$ d12 contain $\mathrm{CNBr}$-cleaved collagen from 1-12 days of heat exposure. The typical CNBr-pattern was observed until day 8, although the decreasing collagen yields indicated extensive collagen degradation and loss (refer to insert in this figure and compare Fig. 1a). From the second day on high-molecular weight peptides disappear (66$116 \mathrm{kDa}$; i.e. missed cleavage products), whereas the electrophoretic pattern of the CNBr-products $(>31 \mathrm{kDa})$ remain stable until day 8 , despite the almost entire loss of collagen. ( $M W$ molecular weight marker)

the case of high latitude permafrost sites, Pleistocene temperature fluctuations) there was a correlation between this thermal age and the extent of deterioration. In bones with thermal ages of $>10_{\mathrm{ka} @ 10^{\circ} \mathrm{C}}$ collagen deterioration was observed in SDS-PAGE electrophoresis as background smears (e.g. 30 and 200 ka samples in Fig. 7b), consisting of peptides of variable molecular weights, similar to those previously reported from Tuross et al. (1980). Bones with thermal ages of $\sim 8_{\mathrm{ka} @ 10^{\circ} \mathrm{C}}$ showed a combination of smearing with some bands still present as observed by Schaedler et al. (1992) in a Columbian mammoth. Two poorly dated Pleistocene fossils from the British Isles (an auroch and a mammoth, unprovenanced, possibly $\sim 30 \mathrm{ka}$ and 200 ka respectively) failed to exhibit clearly visible CNBr-peptide bands.

\section{AAR in CNBr-fragments of different molecular weights in archaeological bones}

In the light of the findings from experimentally degraded collagen (see section AAR in CNBr-fragments of different a
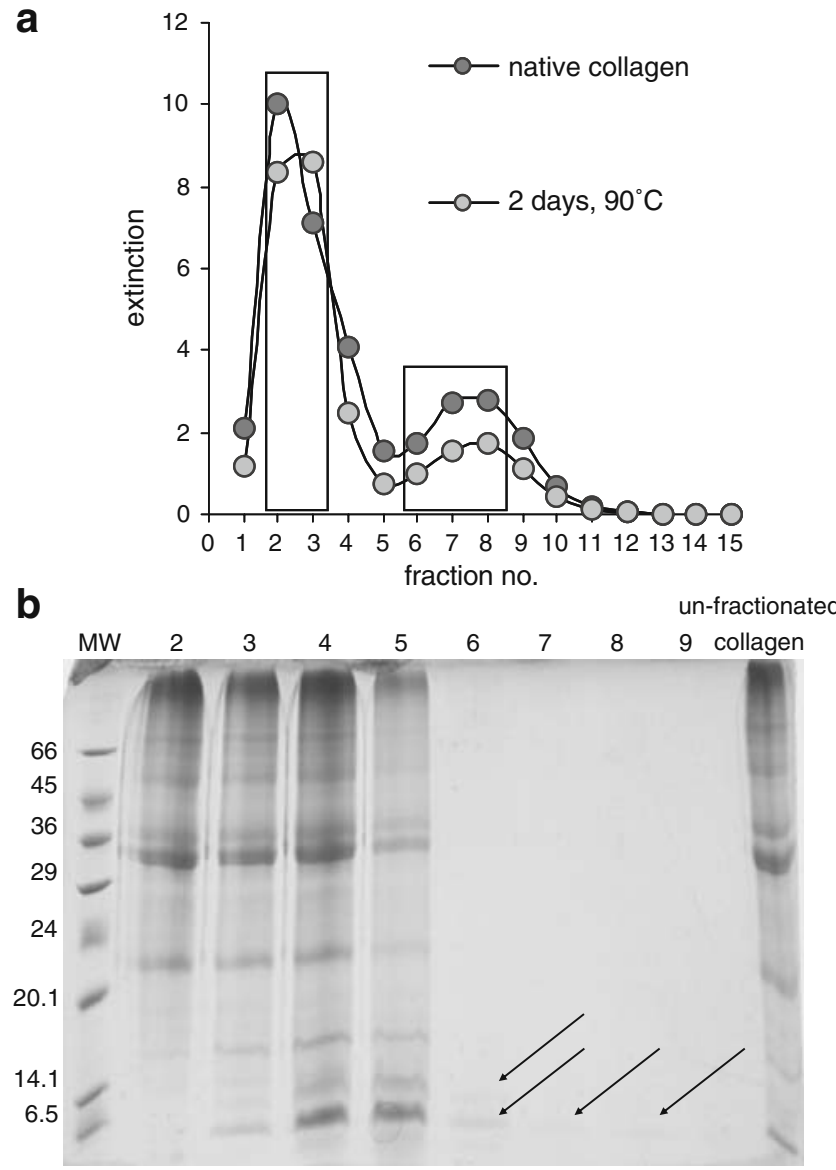

Fig. 4 a Relative concentration of peptides (as revealed by extinction of UV light at $280 \mathrm{~nm}$ ) in gel filtration fractions after group separation of the $\mathrm{CNBr}$-fragments according to their molecular weight (PD10 columns), data represent a native and a heated collagen sample. The marked fractions were collected and analysed subsequently. b Electrophoretic pattern of $\mathrm{CNBr}$-fragments from analysed gel filtration fractions: Fractions 2-5 contained the high molecular weight group ( $\mathrm{MG}>$ ca. $3.5 \mathrm{kD}$ ), fractions $6-9$ the low molecular weight group. Arrows indicate the presence of poorly visible bands of low molecular weight in the photograph, which were clearly visible on the fresh gel

molecular weights in experimentally aged bovine bones), ancient bones were separated into in two high-molecularweight-fractions (fractions 2 and 3; data for fraction 3 is not reported but were similar to fraction 2) and three low-molecular-weight-fractions (fractions 6-8) for detailed AAR analysis. Unlike the $\mathrm{CF}$ fraction of total bone, the high-molecular-weight $\mathrm{CNBr}$-fractions 2 and 3 exhibited relatively constant AAR values for Asx and Ser (similar data in fraction 3, not shown). In contrast, the low molecular weight fractions $(<3.5 \mathrm{kD})$ displayed a very high range of D-Asx and D-Ser values from $4 \%$ up to $16 \%$, but with no clear age dependency either with absolute or thermal age (Fig. 8, fraction 6-8). Interestingly in the low molecular weight fragments there is a sharp decline in D-Asx and D-Ser values from ca. $8_{\mathrm{ka} @ 10^{\circ} \mathrm{C}}$ onwards. 
Fig. 5 Racemisation of aspartic acid / asparagine (Asx, left) and serine (Ser, right) of PD10fractions $1-15$ (CNBr-peptides separated according to their molecular weight by PD10 gel filtration columns. Unheated (0 days) and after experimental collagen degradation at $90^{\circ} \mathrm{C}$ for 2 and 5 days

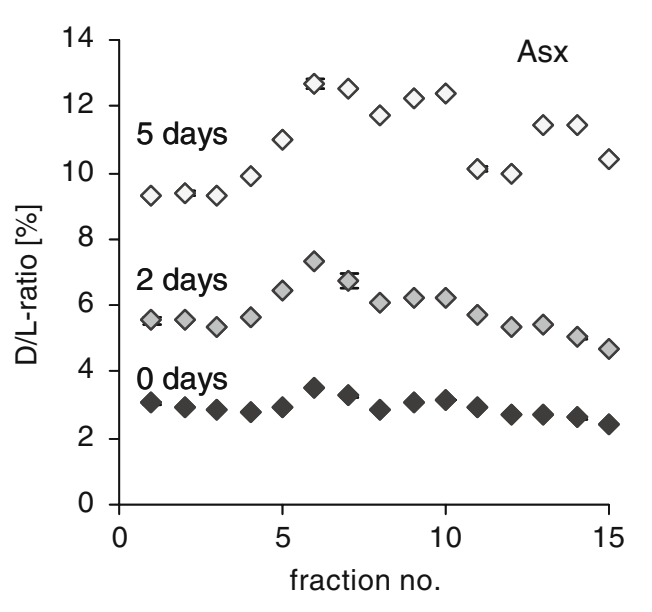

\section{Discussion}

The limited analysis of ancient bone collagen has focussed mainly upon (1) amino acid composition, which appears to change very little (e.g. Hare 1980; Masters 1987) until amino acid compositions are very low, and (2) racemisation, which appears to be highly variable (Weiner et al. 1980; Taylor et al. 1989; Kimber and Hare 1992; Ritz-Timme and Collins 2002), but is lower in high molecular weight fractions. One notable exception to this was the biochemical characterisation conducted by Tuross et al. (1980) and Armstrong et al. (1983), which employed cleavage with CNBr-and pepsin followed by resolution on SDS-PAGE.

Artificial degradation of bones revealed a sigmodial pattern of collagen loss, as previously reported (Rudakova and Zaikov 1987; Okada et al. 1992; Fig. 1a). However the models which have been used to explain this sigmoidal pattern would imply selective loss of unstable amino acids from the charge rich clusters. This is not what is observed in any of the bulk properties of the sample. The amino acid composition, $\mathrm{C}: \mathrm{N}$ ratio, and both bulk isotope estimates $\left(\delta^{13} \mathrm{C}\right.$ and $\left.\delta^{15} \mathrm{~N}\right)$ remained remarkably stable until collagen values fell to less than $1 \%$ of the total weight of the bone. The extent of racemisation (already elevated above the intercept by rapid initial racemisation of the telopeptides) rose slowly but steadily, this is more clearly seen in the human collagen sample, which took longer to gelatinise than the bovine collagen (cf. Figs. 1a and 3), probably because of an age-dependent higher amount of cross-linking between the collagen fibrils.

When only $1 \%$ of collagen remains the measured parameters change very rapidly. In the case of the human bone, two samples in this transition state are observed (23 and 25 days, $0.8 \%$ and $0.3 \%$ by weight collagen). In the case of cattle bone, the change is so rapid, that this state is not observed. This shift can be explained with a mixing model between a dominant pool (collagen) and a much smaller pool of different composition. This pool has not been characterised but may include collagen fragments and non-collagenous bone proteins in addition to non-proteinaceous components such as lipids.
Fig. 6 AAR in crude fractions (CF: dark, TB: light) of archaeological and fossil bone; samples corrected to thermal age and plotted against archaeological age (insert)

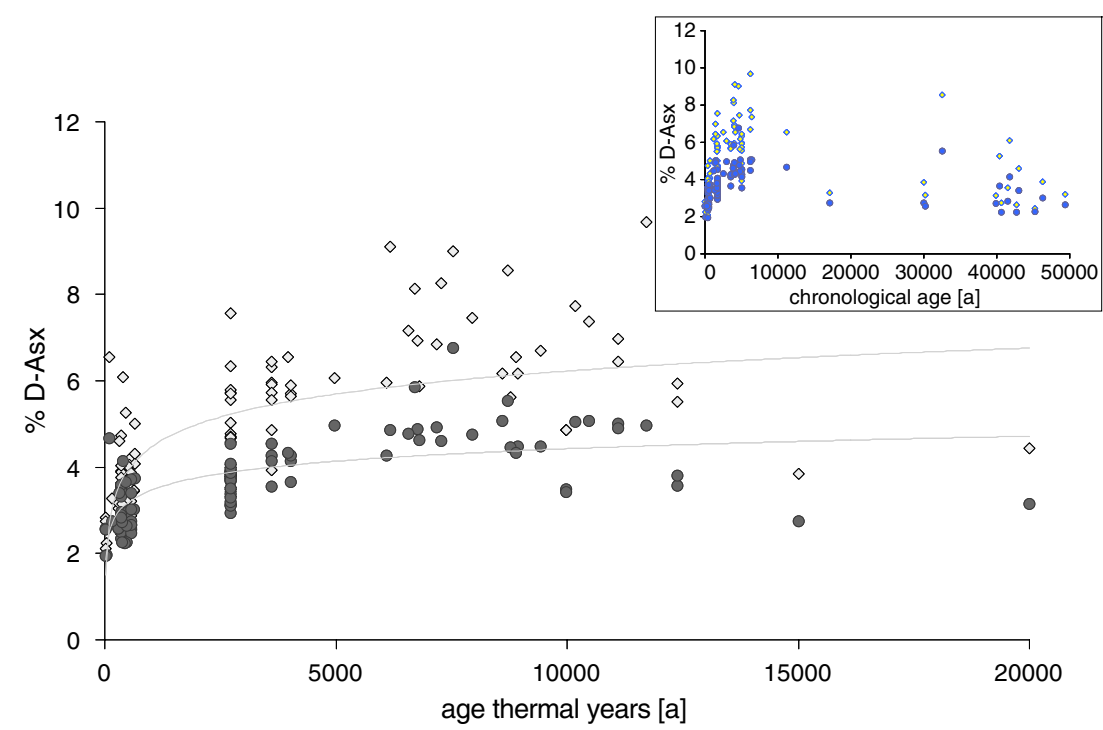




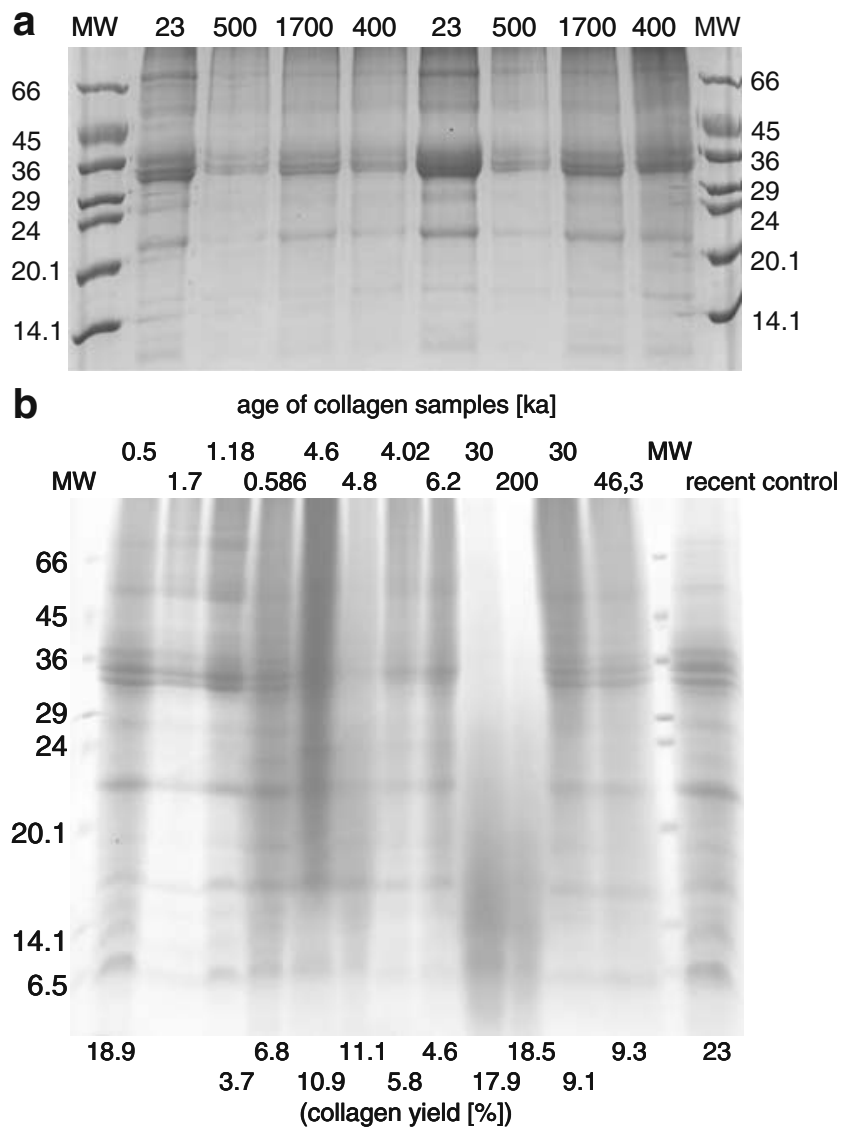

Fig. 7 a Examples of typical CNBr-peptide patterns (SDS-PAGEelectrophoresis) for young archaeological specimens, up to 1,700 years since death. b Examples of typical CNBr-peptide patterns (SDSPAGE-electrophoresis) for archaeological specimens with low yield collagen yields (3.7-5.85\%). Despite variable state of preservation (as assessed by collagen yield or AAR) the $\mathrm{CNBr}$-fragment patterns were remarkably consistent. Age of the collagen samples is given in ka

The overall conclusion to be drawn for this bulk data is that atomic, isotopic and isomeric measurements commonly made on archaeological bone collagen are generally reliable when the insoluble protein levels in bone are $>1 \%$ and amino acid composition is stable.

The typical CNBr-peptide pattern (Fig. 3) persists to protein levels below $1 \%$ of total bone weight. This result indicates that, contra to the polymer degradation model (Collins et al. 1995) hydrolysis is not a random process. Instead, the acid insoluble bone collagen fraction is either present as intact alpha-chains, or absent.

The presence of so much evidence from other proteins so far investigated - predominately from the intra-crystalline fraction of invertebrate biominerals (Weiner et al. 1980; Wehmiller 1993; Johnson and Miller 1997; Collins and Riley 2000), suggest that they should decay in a manner approximating to random chain cleavage, this is not the case for bone collagen. Intact collagen does explain why such crude gelatinisation methods and the use of $30 \mathrm{kDa}$ ultrafiltration is appropriate for most ancient collagen purification as intact collagen is typically present.

The results do, however, suggest that, in bones with thermal ages of $>8_{\mathrm{ka} @ 10^{\circ} \mathrm{C}}$, collagen deterioration may be more complex. These samples display evidence of smearing of variable molecular weight material, as it would be predicted by this model, and which Tuross et al. (1980) observed in three samples (Cave Moa, Tar Pit Smilodon, Egyptian Mummy). One explanation could be that Met has undergone oxidative damage (methionine sulfoxide, can be reversed by 2-mercaptoethanol used in this study, but the second stage of oxidation, methionine sulfone, cannot), and hence $\mathrm{CNBr}$ is no longer an effective method for cleavage. The use of mercaptoethanol to reduce the methionine sulfoxide prior to cleavage may explain those comparatively better $\mathrm{CNBr}$-cleavage patterns we observed when compared to those of Tuross et al. (1980) and Schaedler et al. (1992). It may also be the case that the random hydrolysis of the polymer model does become a more significant factor in older samples, as the smears in the Pleistocene samples were of low molecular weight. Another explanation may be that in older samples there is a greater tendency for cross-linking to modify chain length and result in poor electrophoresis. In concert with hydrolysis, crosslinking may produce the smear observed in these two fossils, but this hypothesis remains to be tested. The presence of low-molecular weight smears in fossil samples was not observed in the artificial diagenesis experiments, revealing that the process of diagenesis is not perfectly modelled. The findings suggest that potentially different strategies are required for collagen purification in samples

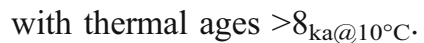

Asx racemisation is a useful probe for the presence of the collagen triple helix in collagen due to the ability of the helix to suppress succinimide formation (van Duin and Collins 1998). For a further refinement of the search for fast racemising Asx-residues within the collagen molecule, we applied separated CNBr-peptides of different molecular weight to AAR.

Separation of a number of $>10_{\mathrm{ka} @ 10^{\circ} \mathrm{C}}$ (i.e. $\mathrm{CNBr}-$ sensible) samples into high and low molecular weight fractions revealed levels observed in the high molecular weight fraction not different than those from preparations of modern collagen (Fig. 8a, b-d), suggesting that the helix remains essentially intact. Similar low levels of racemisation in the insoluble fraction of bone collagen have been reported previously (cf. Matsu'ura and Ueta 1980; Kimber and Hare 1992). Intriguingly, one sample (a wild horse from the Neolithic site) had almost double the levels of AAR of all other samples; it is tempting to speculate that this unusually high value is evidence of cooking, since none of the human samples have such high values. Within intact collagen the only residues free to undergo racemisa- 
Fig. 8 Racemisation of Asx and Ser in collagen-CNBr-peptides from archaeological samples, high molecular weight: fraction 2, low molecular weight: fractions 6-8 (compare with Figs. 4a,b and 5), plotted against thermal age
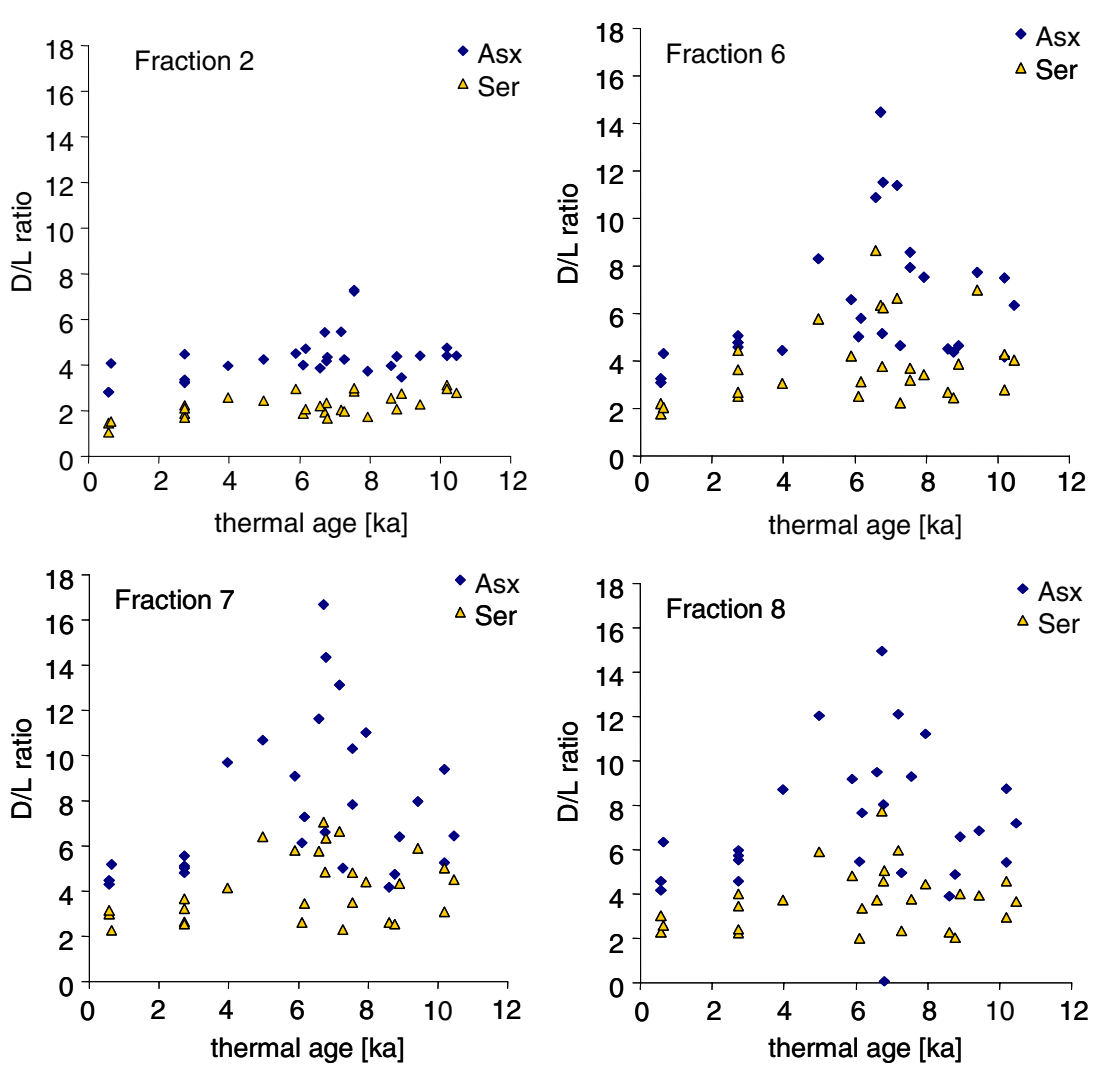

tion are in the telopeptides. These are present in low molecular weight $\mathrm{CNBr}$-products, which is presumably why during artificial ageing the low molecular weight fraction has higher rates of AAR (Fig. 8).

Plotting the net racemisation of the CF against burial and thermal age reveals that only the thermal age displays a trend, and only a weak one. The CF values corrected for thermal age rise to a plateau of approximately 5\% D-Asp. These values are higher than those observed in the high molecular weight $\mathrm{CF}$ fraction, because there is no induced racemisation during the preparation of the CF. Correcting for a $1 \%$-induced racemisation during hydrolysis, this indicates that approximately $8 \%$ of the Asx residues in the CF are undergoing racemisation in the insoluble residue. The speed of this initial rapid rate of racemisation is difficult to assess

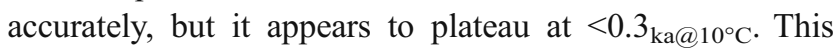
rate is faster than would be predicted based upon the rates of racemisation of the equivalent $\mathrm{CF}$ fraction in dentine at $37^{\circ} \mathrm{C}\left(0.0003\right.$ year $^{-1}$; Ritz et al. 1993), which assuming an activation energy of $94 \mathrm{~kJ} \mathrm{~mol}^{-1}$ (Collins et al. 1999)

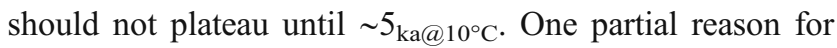
this is the in vivo contribution to this racemisation of this fraction, as has been reported from both, dentine (loc. cit.,) and bone (Ritz et al. 1994), but the rapid rise may be a consequence of the burial environment.

Low racemisation-rates in the $\mathrm{CF}$ of archaeological samples are contrasted with high D-Asx in the leached fraction from the experimental investigation (data not shown). These results are consistent with the model produced by Collins et al. (1999) in which degradation releases fast-racemising soluble components (gelatine), which diffuse out of the bone.

Levels in the total bone are higher than the $\mathrm{CF}$, and these are principally attributed to residual degraded collagen and other bone and allochthonous proteins. NCF has very high and variable levels of racemisation. This effect has been frequently observed (e.g. Matsu'ura and Ueta 1980; Kimber and Hare 1992). Total bone AAR is therefore a reflection not of collagen content or state of preservation but rather the amount of retained soluble protein (Collins et al. 1999). Given the observed pattern of racemisation, it is surprising that AAR in bone has ever proved a good predictor of bone age (e.g. Csapó et al. 1994).

The separation of CNBr-peptides by electrophoresis serves as a sensitive method to identify intact collagen from ancient bone and possibly other hard tissues. As long as a typical CNBr-peptide pattern can be detected, a high 
level of molecular integrity of the remaining collagen can be assumed even in low collagen bones.

\section{Conclusions}

The ubiquity of archaeological bone collagen, and its suitability for radiogenic and stable isotopic analysis tends to obscure the unusual pattern of digenesis. Osteocalcin, an other abundant bone protein (1-2 $\mathrm{mg} \mathrm{g}^{-1}$ bone dry weight) has a highly variable pattern of survival, the mineral binding and hydrophobic domains surviving better than the N-terminus (Smith et al. 2005). Collagen by contrast has a stable amino acid profile and $\mathrm{C}: \mathrm{N}$ ratio until collagen yields fall below $1 \%$. One explanation for this is that the polypeptide remains intact (as evident in the electrophoretic pattern of collagenous CNBr-fragments) even in low collagen archaeological bone. Interestingly, we also observe a different pattern (a smear) in fossil samples, similar to patterns previously reported. The disjunction between these two patterns requires further investigation as it may suggest an alternative pathway of survival of ancient (as opposed to archaeological) collagen. If this is the case, perhaps it may shed light on claims for 'exceptional' preservation of collagen in fossil bones (Palmqvist et al. 2003; Asara et al. 2007).

Acknowledgements The authors wish to express their gratefulness for the allocation of historical bone material to B. Shapiro (Oxford University, Great Britain), I. Schröder (Christian-Albrechts-Universität, Kiel, Germany), and H. Meller (Landesamt für Archäologie SachsenAnhalt, Germany). The work was funded by the Federal Ministry of Education and Research, Germany (no. 03RTX3KI).

\section{References}

Ajie HO, Kaplan IR, Slota PJ, Taylor RE (1990) AMS radiocarbon dating of bone osteocalcin. Nucl Instr Meth B 52:433-437

Ajie HO, Hauschka PV, Kaplan IR, Sobel H (1991) Comparison of bone collagen and osteocalcin for determination of radiocarbon ages and paleodietary reconstruction. Earth Planet Sci Lett 107:380-388

Ajie HO, Kaplan IR, Hauschka PV, Kirner D, Slota PJ, Taylor RE (1992) Radiocarbon dating of bone osteocalcin: isolating and characterizing a noncollagen protein. Radiocarbon 34:296-305

Armstrong WG, Halstead LB, Reed FB, Wood L (1983) Fossil proteins in vertebrate calcified tissue. Phil Trans R Soc Lond B 301:301-343

Asara JM, Schweitzer MH, Freimark LM, Phillips M, Cantley LC (2007) Protein sequences from mastodon and Tyrannosaurus rex revealed by mass spectrometry. Science $316: 280-285$

Brown TA, Nelson DE, Vogel JS, Southon JR (1988) Improved collagen extraction by modified longin method. Radiocarbon 30:171-177
Burky RR, Kirner DL, Taylor RE, Hare PE, Southon JR (1998) C-14 dating of bone using gamma-carboxyglutamic acid and alpha- carboxyglycine (aminomalonate). Radiocarbon 40:1120

Collins MJ, Riley M (2000) The interpretation of aspartic acid racemization data. In: Goodfriend GA, Collins MJ, Fogel ML, Macko SA, Wehmiller JF (eds) Perspectives in amino acid and protein geochemistry. Oxford University Press, Oxford, pp 120144

Collins MJ, Riley MS, Child AM, Turner-Walker G (1995) A basic mathematical simulation of the chemical degradation of ancient collagen. J Archaeol Sci 22:175-183

Collins ML, Waite ER, van Duin ACT (1999) Predicting protein decomposition: the case of aspartic acid racemisation kinetics. Phil Trans Royal Soc Ser B 354:51-64

Corr LT, Sealy JC, Horton MC, Evershed RP (2005) A novel marine dietary indicator utilising compound-specific bone collagen amino acid delta $\mathrm{C}-13$ values of ancient humans. J Archaeol Sci 32:321-330

Csapo J, Csapo-Kiss Z, Nehmehty S, Folestad S, Tivesten A, Martin TG (1994) Age determination based on amino acid racemisation: a new possibility. Amino Acids 7:317-325

Deagle B, Eveson JP, Jarman S (2006) Quantification of damage in DNA recovered from highly degraded samples: a case study on DNA in faeces. Frontiers Zool 3:11

DeNiro MJ (1985) Postmortem preservation and alteration of in vivo bone collagen isotope ratios in relation to palaeodietary reconstruction. Nature 317:806-809

Fietzek PP, Wendt P, Kell I, Kühn K (1972) The covalent structure of collagen: amino acid sequence of $\alpha 1-\mathrm{CB} 3$ from calf skin collagen. FEBS Lett 26:74-76

Fogel ML, Tuross N (2003) Extending the limits of paleodietary studies of humans with compound specific carbon isotope analysis of amino acids. J Archaeol Sci 30:535-545

Goodfriend GA, Hare PE, Druffel ERM (1992) Aspartic-acid racemization and protein diagenesis in corals over the last 350 years. Geochim Cosmochim Acta 56:3847-3850

Grupe G, Turban-Just S (1998) Amino acid composition of degraded matrix collagen from archaeological human bone. Anthrop Anz $56: 213-226$

Hare PE (1980) Organic geochemistry of bone and its relation to the survival of bone in the natural environment. In: Behrensmeyer AK, Hill AP (eds) Fossils in the making: vertebrate taphonomy and palaeoecology. Chicago University Press, Chicago, pp 208219

Higham TFG, Jacobi RM, Ramsey CB (2006) Radiocarbon dating of ancient bone using ultrafiltration. Radiocarbon 48:179-195

Hill RL (1965) Hydrolysis of proteins. Adv Protein Chem 20:37107

Howland MR, Corr LT, Young SMM, Jones V, Jim S, van der Merwe NJ, Mitchell AD, Evershed RP (2003) Expression of the dietary isotope signal in the compound-specific $\delta{ }^{13} \mathrm{C}$ values of pig bone lipids and amino acids. Int $J$ Osteoarchaeol 13:54-65

Jim S, Jones V, Ambrose SH, Evershed RP (2006) Quantifying dietary macronutrient sources of carbon for bone collagen biosynthesis using natural abundance stable carbon isotope analysis. Brit $\mathrm{J}$ Nutr 95:1055-1062

Johnson BJ, Miller GH (1997) Archaeological applications of amino acid racemization. Archaeometry 39:265-287

Jope EM (1980) Ancient bone and plant proteins: the molecular state of preservation. In: Hare PE, Hoering C, King K Jr (eds) Advances in biogeochemistry of amino acids. Carnegie Institute, Washington DC, pp 23-33 
Kaufman DS, Manley WF (1998) A new procedure for determining DL amino acid ratios in fossils using reverse phase liquid chromatography. Quat Geochronol 17:987-1000

Kimber RWL, Hare PE (1992) Wide-range of racemisation of aminoacids in peptides from human fossil bone and its implications for amino-acid racemisation dating. Geochim Cosmochim Acta 56:739-743

Knott L, Tarlton JF, Bailey AJ (1997) Chemistry of collagen crosslinking: biochemical changes in collagen during partial mineralisation of turkey leg tendon. Biochem J 322:535-542

Laemmli UK (1970) Cleavage of structural proteins during the assembly of the head of bacteriophage T4. Nature 227:680-685

Masters PM (1987) Preferential preservation of non-collagenous protein during bone diagenesis: implications for chronometric and stable isotopic measurements. Geochim Cosmochim Acta 51:3209-3214

Matsu'ura S, Ueta N (1980) Fraction dependent variation of aspartic acid racemisation age of fossil bone. Nature 286:883-884

Okada T, Hayashi T, Ikada Y (1992) Degradation of collagen suture in vitro and in vivo. Biomaterials 13:448-454

Palmqvist P, Grocke DR, Arribas A, Farina RA (2003) Paleoecological reconstruction of a lower pleistocene large mammal community using biogeochemical $\delta^{13} \mathrm{C}, \delta{ }^{15} \mathrm{~N}, \delta{ }^{18} \mathrm{O}, \mathrm{Sr}: \mathrm{Zn}$ ) and ecomorphological approaches. Paleobiology 29:205-229

Piez KA, Reddi AH (1984) Extracellular matrix biochemistry. Elsevier, New York

Poinar HN, Schwarz C, Qi J, Shapiro B, MacPhee RDE, Buigues B, Tikhonov A, Huson DH, Tomsho LP, Auch A, Rampp M, Miller W, Schuster SC (2006) Metagenomics to paleogenomics: largescale sequencing of mammoth DNA. Science 311:392-394

Ramsey CB, Higham T, Bowles A, Hedges R (2004) Improvements to the pretreatment of bone at Oxford. Radiocarbon 46:155-163

Riley MS, Collins MJ (1994) The polymer model of collagen degradation. Polymer Degrad Stabil 46:93-97

Ritz-Timme S (1999) Lebensaltersbestimmung aufgrund des Razemisierungsgrades von Asparaginsäure: Grundlagen, Methodik, Möglichkeiten, Grenzen, Anwendungsbereiche. In: Berg S und, Brinkmann B (eds) Arbeitsmethoden der medizinischen und naturwissenschaftlichen Kriminalistik, vol 23. Schmidt Römhild, Lübeck, Germany

Ritz-Timme S, Collins MJ (2002) Racemization of aspartic acid in human proteins. Ageing Res Revs 1:43-59

Ritz S, Schütz HW, Peper C (1993) Postmortem estimation of age at death based on aspartic acid racemisation in dentin: its applicability for root dentin. Int J Legal Med 105:189-293

Ritz S, Turzynski A, Schütz HW (1994) Estimation of age at death based on aspartic acid racemization in non-collagenous bone proteins. Forensic Sci Int 69:149-159

Ritz S, Turzynski A, Schütz HW, Hollmann A, Rochholz G (1996) Identification of osteocalcin as a permanent aging constituent of the bone matrix: basis for an accurate age at death determination. Forensic Sci Int 770:13-26

Ritz-Timme S, Rochholz G, Schütz HW, Collins MJ, Waite ER, Cattaneo C, Kaatsch H-J (2000) Quality assurance in age estimation based on aspartic acid racemisation. Int J Legal Med 114:83-86

Rossi A, Zuccarello LV, Zanaboni G, Monzani E, Dyne KM, Cetta G, Tenni R (1996) Type I collagen CNBr peptides: species and behaviour in solution. Biochem 35:6048-6057

Rudakova TE, Zaikov GE (1987) Degradation of collagen and its possible applications in medicine. Polymer Degrad Stabil 18:271-291
Saban MD, Cassidy RM, Scott JD (1992) Collagen proteins in electrorefining: rate constants for glue hydrolysis and effects of molar mass on glue activity. Metallurg Mat Trans B 23:125133

Schaedler JM, Krook L, Wootton JAM, Hover B, Brodsky B, Naresh MD, Gillette DD, Madsen DB, Horne RH, Minor RR (1992) Studies of collagen in bone and dentin matrix of a Columbian mammoth (Late Pleistocene) of central Utah. Matrix 12:297-307

Scott PG, Veis A (1976) The cyanogen bromide peptides of bovine soluble and insoluble collagens. I. Characterisation of peptides from soluble type I collagen by sodium dodecylsulphate polyacrylamide gel electrophoresis. Conn Tissue Res 4:107116

Serre D, Langaney A, Chech M, Teschler-Nicola M, Paunovic M, Mennecier P, Hofreiter M, Possnert G, Pääbo S (2004) No evidence of Neandertal mtDNA contribution to early modern humans. PLoS Biology 2:e57

Smith CI, Chamberlain AT, Riley MS, Stringer C, Collins MJ (2003) The thermal history of human fossils and the likelihood of successful DNA amplification. J Human Evol 45:203-217

Smith CI, Craig OE, Prigodich RV, Nielsen-Marsh CM, Jans MME, Vermeer C, Collins MJ (2005) Diagenesis and survival of osteocalcin in archaeological bone. J Archaeol Sci 32:105-113

Takagi Y, Veis A (1984) Isolation of phosphophoryn from human dentin organic matrix. Calcif Tissue Int 36:259-265

Taylor RE, Ennis PJ, Slota PJ, Payen LA (1989) Non-age-related variations in aspartic-acid racemisation in bone from a radiocarbon-dated late Holocene archaeological site. Radiocarbon 31:1048-1056

Tripp JA, McCullagh JSO, Hedges REM (2006) Preparative separation of underivatized amino acids for compound-specific stable isotope analysis and radiocarbon dating of hydrolyzed bone collagen. J Sep Sci 29:41-48

Tuross N, Eyre DR, Holtrop ME, Glimcher MJ, Hare PE (1980) Collagen in fossil bones. In: Hare PE, Hoering TC, King K Jr (eds) Biogeochemistry of amino acids. Wiley., New York, pp 5363

van der Rest M, Fietzek PP (1982) A comprehensive approach to the study of collagen primary structure based on high-performance liquid chromatography. Eur J Biochem 125:491-496

van Duin AC, Collins MJ (1998) The effects of conformational constraints on aspartic acid racemisation. Org Geochem 29:1227-1232

van Klinken GJ (1999) Bone collagen quality indicators for palaeodietary and radiocarbon measurements. J Archaeol Sci 26:687695

Volpin D, Veis A (1973) Cyanogen bromide peptides from insoluble skin and dentin bovine collagens. Biochemistry 12:1452-1464

Waite ER, Collins MJ (2000) The interpretation of aspartic acid racemization of dentine proteins. In: Goodfriend GA, Collins MJ, Fogel ML, Macko SA, Wehmiller JF (eds) Perspectives in amino acid and protein geochemistry. Oxford University Press, Oxford, pp 182-194

Wehmiller JF (1993) Applications of organic geochemistry for quaternary reserach; aminostratigraphy and aminochronology. In: Engle MH, Macko SA (eds) Organic geochemistry. Plenum, New York, pp 755-783

Weiner S, Kustanovich Z, Gil-Av E, Traub W (1980) Dead Sea scrolls parchments: unfolding of the collagen molecules and racemisation of aspartic acid. Nature 287:820-823 